RESIDENT

\& FELLOW

SECTION

Section Editor

Mitchell S.V. Elkind,

MD, MS

W.D. Freeman, MD

C.M. Nolte, MD

B.R. Matthews, MD

M. Coleman, BS

J.R. Corboy, MD

Address correspondence and reprint requests to Dr. John R. Corboy, 12631 East 17 th Street, PO Box 6511, Mailstop B-185, Aurora, CO 80045

john.corboy@ucdenver.edu

\section{Results of the American Academy of Neurology Resident Survey}

\section{ABSTRACT}

Background: To assess the effect of neurology residency education as trainees advance into independent practice, the American Academy of Neurology (AAN) elected to survey all graduating neurology residents at time of graduation and in 3-year cycles thereafter.

Methods: A 22-question survey was sent to all neurology residents completing residency training in the United States in 2007.

Results: Of 523 eligible residents, 285 (54.5\%) responded. Of these, 92\% reported good to excellent quality teaching of basic neurology from their faculty; however, $47 \%$ noted less than ideal training in basic neuroscience. Two-thirds indicated that the Residency In-service Training Examination was used only as a self-assessment tool, but reports of misuse were made by some residents. After residency, 78\% entered fellowships (with 61\% choosing a fellowship based on interactions with a mentor at their institution), whereas $20 \%$ entered practice directly. After adjustment for the proportion of residents who worked before the duty hour rules were implemented and after their implementation, more than half reported improvement in quality of life $(87 \%)$, education $(60 \%)$, and patient care $(62 \%)$. The majority of international medical graduates reported wanting to stay in the United States to practice rather than return to their country of residence.

Conclusions: Neurology residents are generally satisfied with training, and most entered a fellowship. Duty hour implementation may have improved resident quality of life, but reciprocal concerns were raised about impact on patient care and education. Despite the majority of international trainees wishing to stay in the United States, stricter immigration laws may limit their entry into the future neurology workforce. Neurology ${ }^{\circledR} 2011 ; 76$ :e61-e67

\section{GLOSSARY}

AAN = American Academy of Neurology; ACGME = Accreditation Council for Graduate Medical Education; CNRF = Consortium of Neurology Residents and Fellows; GES = Graduate Education Subcommittee; IMG = international medical graduate; MDS = Member Demographics Subcommittee; RITE = Residency In-service Training Examination.

The neurology education process has changed since $2000 \cdot{ }^{1-3}$ Previously, residents had virtually unlimited hours, providing the backbone of care. In 2003, the Accreditation Council for Graduate Medical Education (ACGME) restricted resident work hours to 80 hours/week. In addition, limited funds and dwindling reimbursement have increased pressures to see more patients, reducing teaching time.

The Workforce Task Force of the American Academy of Neurology (AAN) charged the Graduate Education Subcommittee (GES) with studying the quality of neurology residency education ${ }^{4}$ because of these pressures and concerns about neurology's future and the quality of resident training. It was proposed that neurology trainees be surveyed directly after graduation from neurology residency training and at 3-year cycles thereafter. These data would provide the AAN with feedback about the quality of neurology residencies and help define the residency process. Finally, these data

From the Department of Neurology (W.D.F.), Mayo Clinic College of Medicine, Jacksonville, FL; Department of Sleep Medicine (C.M.N.), Vanderbilt University, Nashville, TN; Department of Neurology (B.R.M.), Indiana University School of Medicine, Indianapolis; American Academy of Neurology (M.C.), St. Paul, MN; and Department of Neurology (J.R.C.), University of Colorado School of Medicine and Denver Veterans Affairs Medical Center, Denver.

Disclosure: Author disclosures are provided at the end of the article. 
would provide feedback to the ACGME and neurology residency program directors for tailoring programs.

METHODS The GES and Consortium of Neurology Residents and Fellows (CNRF) created an initial draft as a 3-part survey. After AAN staff review, the scope of the research was narrowed, and a condensed version was sent to the Member Demographics Subcommittee (MDS). The MDS reviewed and provided suggestions. A final survey was completed in 2007 and distributed via e-mail and postal mail (figure).

All neurology residents $(n=633)$ who completed training in the United States in 2007 were eligible. AAN, GES, MDS, and CNRF members who requested or reviewed the survey were ineligible for participation. In addition, residents who received 3 AAN surveys in the past 3 years were removed according to AAN policy. Those who contacted the AAN to indicate that they were still residents and those who did not have accurate contact information were also removed; the final sample size was 523 .

RESULTS The survey had a response rate of $54.5 \%$ (285 of 523). The margin of error for respondents was $\pm 4.4 \%$ ( $95 \%$ confidence interval). There were no differences in demographic data of gender or age between respondents and nonrespondents. The full AAN survey report can be found at www.aan.com/ go/education/residents.

Most residents felt that they were well-trained, providing a "good" to "excellent" rating of supervision and training in a variety of clinical settings. Greater than 90\% felt they were "well" or "very well" prepared in diagnostic formulation and patient management, rating the quality of teaching by faculty as "good" or "excellent" (40\% and 52\%, respectively).

About half (53\%) felt that their training program did "well" or "very well" in providing didactic material in basic neurosciences. However, when asked to rate their residency on practice issues, at least $70 \%$ reported "fair" to "poor" preparation in billing, contracts, malpractice, coding, and office management issues (figure, question 20).

More than three-quarters of residents entered fellowship training after residency, and $87 \%$ were satisfied with their offers. The selection of a fellowship program was often based on a mentor at their institution $(61 \%)$, and $80 \%$ of residents selected a clinical fellowship. The 3 most common fellowships were neurophysiology (42\%), movement disorders (9\%), and sleep medicine (9\%). After fellowship, 33\% expected to enter academic practice, and $28 \%$ planned to enter private practice. The rest planned to enter research, research and clinical practice, or another fellowship, or were unsure (figure, question 17).

About one-third of residents claimed that they always worked under duty hour restrictions (figure, question 2). They are the "uniform" group, because they could not appreciate the impact "before and af- ter" of duty hours regulations. The remaining twothirds were residents before and after ACGME duty hours were implemented. They are the "transitional" group. It is important to note that ACGME duty hour rules went into effect on July 1, 2003, ${ }^{5}$ and the survey targeted all graduating residents in July 2007. Therefore, the duty hour violation reports of the transitional group may have occurred as part of their training before 2003, when the duty hours were not in effect. These responses were impossible to interpret based on the limited survey questions.

Responses indicated improvement in patient care (62\%), education (60\%), and quality of life ( $87 \%)$ as a consequence of reduced hours. The response rate was adjusted, and the proportion among responses was corrected (\% response/66\%) The transitional group reported no change or worsening in patient care $(23 \%, 15 \%)$, no change or worsening in education $(27 \%, 13 \%)$, and no change or worsening in quality of life $(12 \%, 1 \%)$ after implementation.

Two-thirds of respondents only used their Residency In-service Training Examination (RITE) scores for improvement, but about $15 \%$ voiced concerns that their scores were used for other purposes. These uses included resident comparison, basis for awards, fellowship applications, and funding opportunities.

Of the 56 who were foreign medical graduates without a green card, $79 \%$ intended to stay in the United States after training, whereas 16\% planned to return home.

DISCUSSION This survey is among the largest of neurology residents to date ${ }^{5-7}$ and suggests positive and negative impressions about training. Trainees feel positive about core training of diagnoses and patient care but less positive about basic neuroscience and practice-related issues. Nearly half (47\%) reported deficiencies in basic neuroscience, and at least $70 \%$ reported deficiencies in business practice areas. These may be due to a lack of defined instructors. ${ }^{2,3}$ Based on this information, the AAN offers trainees a 6-part basic science course over a 3-year cycle at AAN annual meetings. The perceived deficiency in business aspects of medicine has been brought to the AAN leadership. It may reflect the fact that neurology residency programs do not teach business well, or it may reflect the complex nature of billing and coding.

Residents historically ${ }^{2}$ choose to participate in continued training through fellowship. Most appear happy with their mentoring and postresidency training options. Mentor influence on selection of a particular subspecialty appears evident in this survey and has been observed in other medical subspecialties. ${ }^{8}$ We did not ask why fellowships were chosen, but choices probably reflected areas of interest. Other 
1. How would you characterize your activities in neurology directly after your residency? $(\mathrm{N}=\mathbf{2 8 3})$
$39.2 \% \quad$ Fellowship training at residency institution
$38.5 \%$ Fellowship training at another institution
$19.8 \%$ Went into practice
$0.4 \%$ Returned to home country

\author{
$0.0 \%$ Went to PHARMA \\ $0.7 \%$ Left neurology \\ $0.0 \%$ Left medicine \\ $1.4 \%$ Other
}

\section{Duty Work Hours}

\section{How did ACGME duty work hours affect the following:}

a. Patient care $(\mathrm{N}=282)$

b. Resident education $(\mathrm{N}=283)$

c. Resident quality of life $(\mathrm{N}=283)$

"This group of residents did not always work under the duty hours , and could compare "before" and "after" the duty hour implementation. The other group of residents** started training after the duty hours were implemented and always worked under these regulations.

\section{Residency Training Program}

Questions 3 to 5: How well did your residency program do on the following:
3. Preparing you to make adequate diagnostic

Very

well formulations $(\mathrm{N}=282)$

4. Preparing you adequately for patient management $(\mathrm{N}=281)$

5. Providing didactic material for each category below:
a. Basic science $(\mathrm{N}=284)$
b. Clinical skills $(\mathrm{N}=284)$
$15.5 \%$
$47.5 \%$
$37.7 \%$
$42.6 \%$
$37.3 \%$
$46.5 \%$
$28.2 \%$
$39.8 \%$
d. Subspecialty training $(\mathrm{N}=284$
$24.6 \%$
$47.7 \%$

Always** worked under duty hour rules so cannot compare $33.9 \%$ $32.5 \%$ $34.0 \%$

6. Please rate the diversity of your residency training program for the following rotations (diversity includes the depth and breadth of patient cases and disease entities):

a. Continuity clinic $(\mathrm{N}=284)$

b. Inpatient rotations $(\mathrm{N}=284)$

c. Pediatric neurology rotations $(\mathrm{N}=284)$

d. Subspecialty clinic $(\mathrm{N}=284)$

e. Subspecialty rotations $(\mathrm{N}=283)$

$\begin{array}{cccc}\begin{array}{c}\text { Very } \\ \text { diverse }\end{array} & \begin{array}{c}\text { Somewhat } \\ \text { diverse }\end{array} & \begin{array}{c}\text { Not } \\ \text { diverse }\end{array} & \begin{array}{c}\text { N/A } \\ 29.6 \%\end{array} \\ 56.0 \% & 14.4 \% & 0.0 \% \\ 61.6 \% & 35.2 \% & 3.2 \% & 0.0 \% \\ 45.8 \% & 45.4 \% & 7.4 \% & 1.4 \% \\ 50.0 \% & 40.8 \% & 6.3 \% & 2.8 \% \\ 43.5 \% & 47.0 \% & 6.7 \% & 2.8 \%\end{array}$

7. Please rate your residency program on the following:

a. Inpatient-ward supervising/teaching physicians $(\mathrm{N}=284)$

b. Continuity clinic supervising/teaching physicians $(\mathrm{N}=284)$

c. Subspecialty supervising/teaching physicians $(\mathrm{N}=284)$

$\begin{array}{ccccc}\begin{array}{c}\text { Excellent } \\ 56.7 \%\end{array} & \text { Good } & \text { Fair } & \text { Poor } & \text { N/A } \\ & 34.9 \% & 6.7 \% & 1.8 \% & 0.0 \% \\ 42.6 \% & 42.3 \% & 10.9 \% & 3.5 \% & 0.7 \% \\ 52.1 \% & 38.4 \% & 6.7 \% & 2.1 \% & 0.7 \%\end{array}$


8. Overall, what was the quality of the teaching from the neurology faculty in the institution you completed your residency? $(\mathrm{N}=274)$
$52.2 \% \quad$ Excellent
$40.1 \%$ Good
$6.2 \% \quad$ Fair
$1.5 \%$ Poor

9. Please rate your non-neurology residency supervising faculty:

$\begin{array}{lccccc} & \text { Excellent } & \text { Good } & \text { Fair } & \text { Poor } & \text { N/A } \\ \text { a. Pathology }(\mathrm{N}=283) & 41.3 \% & 39.9 \% & 11.0 \% & 3.5 \% & 4.2 \% \\ \text { b. Radiology }(\mathrm{N}=284) & 41.5 \% & 35.2 \% & 15.8 \% & 4.9 \% & 2.5 \% \\ \text { c. Neurosurgery }(\mathrm{N}=283) & 17.3 \% & 40.3 \% & 17.3 \% & 4.9 \% & 20.1 \% \\ \text { d. Rehabilitation }(\mathrm{N}=283) & 10.6 \% & 34.6 \% & 18.4 \% & 5.7 \% & 30.7 \% \\ \text { e. Psychiatry }(\mathrm{N}=284) & 15.8 \% & 42.3 \% & 26.4 \% & 6.7 \% & 8.8 \%\end{array}$

10. Are there any areas or topics that would have helped to prepare you for fellowship or practice that were not taught? $(\mathrm{N}=278)$

$$
36.7 \% \quad \text { Yes (go to question 10a) } \quad 63.3 \% \quad \text { No (go to question 11) }
$$

10a. If yes, what areas (please specify):

See survey comments

\section{Residency In-service Training Examination (RITE)}

11. The RITE helped define areas for my self-study to strengthen my neurologic knowledge. $(\mathrm{N}=\mathbf{2 8 3})$

$\begin{array}{llll}18.4 \% & \text { Strongly agree } & 7.8 \% & \text { Disagree } \\ 54.8 \% & \text { Agree } & 2.8 \% & \text { Strongly disagree } \\ 16.3 \% & \text { Neutral } & & \end{array}$

12. Was your RITE score used for any other purpose other than self-study improvement (e.g., comparison to other residents, fellowship acceptance, honors)? $(\mathrm{N}=\mathbf{2 8 3})$
$14.5 \%$ Yes
(go to question 12a)
$66.1 \%$ No
(go to question 13)
19.4\% Unsure
(go to question 13)

12a. If yes, explain:

See survey comments

13. I was satisfied with the mentoring available in my residency program in guiding me to find a fellowship and/or career after residency. $(\mathrm{N}=\mathbf{2 8 2})$
$28.4 \%$ Strongly agree
$39.7 \%$ Agree
$6.7 \%$ Disagree
$22.7 \%$ Neutral
$2.5 \%$ Strongly disagree

Fellowship (If you did not enter a fellowship please skip to QUESTION 20)

14. What type of fellowship are you in? $(\mathrm{N}=220)$

$1.4 \%$ Basic science research

$79.5 \%$ Clinical fellowship
$14.5 \%$ Clinical research fellowship

4.5\% Mixture of basic science research and clinical research 
15. What is your area of fellowship training? $(\mathrm{N}=\mathbf{2 2 2})$

$\begin{array}{llll}2.7 \% & \text { Behavioral } & 1.8 \% & \text { Neuro-ophthalmology } \\ 7.7 \% & \text { Cerebrovascular } & 3.6 \% & \text { Neurocritical care } \\ 0.5 \% & \text { General } & 42.3 \% & \text { Neurophysiology (EMG, EEG) } \\ 9.0 \% & \text { Movement Disorder } & 0.9 \% & \text { Research } \\ 5.4 \% & \text { Multiple Sclerosis } & 26.1 \% & \text { Other (please specify): }\end{array}$

16. How long is your fellowship? (Please mark only one) $(\mathrm{N}=222)$
$65.8 \%$ One year
$5.4 \% \quad$ Three years or longer
$26.6 \%$ Two years
$2.3 \%$ Other (please specify):

17. At the end of your fellowship, what type of practice do you expect to enter? (Please mark only one $)(\mathrm{N}=223)$
$32.7 \% \quad$ Academic practice
$0.0 \%$ Basic science research
$4.5 \%$ Basic science research with part-time clinical practice
$10.3 \%$ Clinical $/$ clinical research
$4.0 \%$ Clinical research with part-time clinical practice
$15.2 \%$ Not sure yet
$0.4 \%$ Pharmaceutical industry
$28.3 \%$ Private practice
$4.5 \%$ Other (please specify):

18. How did you select a fellowship program? $(\mathrm{N}=218)$
$17.0 \% \quad$ AAN online fellowship directory
$1.4 \%$ Networking at the Annual Meeting
$3.7 \%$ Mentor in another institution
$5.0 \%$ Program Director
$60.6 \%$ Mentor in my institution
$12.4 \%$ Other (please specify):

19. How satisfied were you with the fellowship offers you received? $(\mathrm{N}=\mathbf{2 1 8})$
$61.0 \%$ Very satisfied
$26.1 \%$ Somewhat satisfied
$3.2 \% \quad$ Somewhat dissatisfied
$9.2 \% \quad$ Neutral
$0.5 \%$ Very dissatisfied

20. Please rate your residency on preparing you for the following practice issues:
a. Billing $(\mathrm{N}=283)$
Excellent
$6.7 \%$
$2.5 \%$
$2.5 \%$
$5.7 \%$
Fair
Poor
N/A
b. Contracts $(\mathrm{N}=283)$
$20.1 \%$
$33.9 \%$
$35.7 \%$
$3.5 \%$
$10.6 \%$
$31.1 \%$
$49.5 \%$
$6.4 \%$
c. Malpractice $(\mathrm{N}=282)$
$16.3 \%$
$35.5 \%$
$39.7 \%$
$6.0 \%$
d. Coding $(\mathrm{N}=283)$
$18.7 \%$
$32.9 \%$
$37.8 \%$
$4.9 \%$
e. Office management $(\mathrm{N}=283)$
$1.8 \%$
$10.2 \%$
$28.3 \%$
$51.9 \% \quad 7.8 \%$

Good

21. If you completed medical school outside of the US, and are not a US resident and do not have a green card, after all your training is completed, your intention is to:

(N=56)

$16.1 \%$ Return to my country of origin for practice

$78.6 \%$ Stay in the US for practice

$5.4 \%$ Go to a third country for practice

22. Please provide any comments you may have on the topic of this survey.

(free-text comments) 
considerations included financial issues, such as income or debt. It is also possible that trainees feel that the standard training period is inadequate to teach all complications of neurologic practice, and fellowship is a period of strengthening within their area of interest. An additional year of core neurology residency has been considered to compensate for the growing body of knowledge, but it is not favored., ${ }^{2,3}$ RITE scores were another concern. Although nearly threequarters $(73 \%)$ of residents agreed that the RITE helped in self-study, the remaining felt that the examination was used for purposes other than selfstudy. The AAN RITE Advisory Panel has responded to these data and will now include a short survey in the RITE about resident perception of the RITE (F. Flynn, personal communication, 2009). The AAN's position has always been that the RITE is solely for resident self-instruction, not for intraresidency comparison or fellowships. We emphasize that there are limited conclusions to be drawn from this response, and future refinement is required.

Question 2 was the only question about the impact of duty hours on patient care, education, and quality of life. We did not specifically assess duty hour violations with other fields. ${ }^{9}$ The impact of ACGME duty hours on the quality of residency education has been debated. ${ }^{7,9}$ The current survey was not meant to address all aspects of this impact. It addressed general educational topics encountered during neurology training. The table summarizes a survey about ACGME duty hours ${ }^{3}$ that disagrees with our survey. Overall, program directors reported a more negative impact of ACGME duty hours on patient care and education than the residents. ${ }^{3}$ Some respondents felt that there was a lack of enforcement of the regulations in fellowship programs. Given the possibilities of overanalyzing the limited data, we hope to refine the questions about the impact of duty hours in future surveys. Nonetheless, we found the data intriguing because they captured a group of residents who reported both working and not working under the duty hour regulations.

A recent analysis showing that the present restrictions have not done enough to promote patient safety may lead to further work hour restrictions. ${ }^{10}$ Some residency programs have hired neurohospitalists or physician extenders to bridge the gap in patient care as a result. However, these models may incur additional administrative costs. It remains to be proven whether reduced resident hours improve patient safety.

Finally, the majority of international medical graduates (IMGs) without appropriate visas or citizenship status reported they would like to stay in the United States after training (question 21). Exceptions to allow IMGs to stay in the United States are now harder to receive. Therefore, changes in the numbers of IMGs staying in the United States will affect the numbers of future neurologists.

Recommendations. This survey should be given every 3 years to examine the educational process and to assess changes in resident perception. In addition, repeating the survey will provide program directors and the ACGME with information about the quality of neurology education process. Future surveys could include the impact of ACGME work hour restrictions $^{7}$ on sleep and fatigue, quality-of-life issues, and

\begin{tabular}{|c|c|c|c|c|c|c|c|c|}
\hline \multirow[t]{4}{*}{ Table } & $\begin{array}{l}\text { of ACGME d } \\
\text { current sur }\end{array}$ & $\begin{array}{l}\text { rork hours } \\
\text { esults (que }\end{array}$ & $\begin{array}{l}\text { sidents and } \\
\text { 2), which co }\end{array}$ & $\begin{array}{l}\text { neurology } \\
\text { re and cont }\end{array}$ & $\begin{array}{l}\text { am director } \\
\text { views of resi }\end{array}$ & $\begin{array}{l}\text { dified from } \\
s \text { and progr }\end{array}$ & $\begin{array}{l}\text { het al. }{ }^{3} \text { ) an } \\
\text { rectors }\end{array}$ & combined \\
\hline & \multicolumn{6}{|c|}{$\begin{array}{l}\text { Transitional group of residents who worked before ACGME duty hour regulations and then after } \\
\text { their implementation in } 2003, \%\end{array}$} & \multirow{2}{*}{\multicolumn{2}{|c|}{$\begin{array}{l}\text { Residents who always } \\
\text { worked under duty hour } \\
\text { rules so cannot compare } \\
\text { (uniform group), \% }\end{array}$}} \\
\hline & \multicolumn{2}{|l|}{ Improved $^{\mathrm{a}}$} & \multicolumn{2}{|l|}{ Worsened $^{a}$} & \multicolumn{2}{|l|}{ No change ${ }^{a}$} & & \\
\hline & Residents $^{a}$ & $\begin{array}{l}\text { Program } \\
\text { directors }^{3}\end{array}$ & Residents $^{a}$ & $\begin{array}{l}\text { Program } \\
\text { directors }^{3}\end{array}$ & Residents $^{a}$ & $\begin{array}{l}\text { Program } \\
\text { directors }^{3}\end{array}$ & Residents $^{b}$ & $\begin{array}{l}\text { Program } \\
\text { directors }^{3}\end{array}$ \\
\hline Patient care & $41.1\left(61^{c}\right)$ & 8.1 & $9.6\left(14^{c}\right)$ & 40.4 & $15.2\left(22^{c}\right)$ & 51.5 & 34.0 & NA \\
\hline Resident education & $39.6\left(60^{c}\right)$ & 15.0 & $8.8\left(13^{c}\right)$ & 61.0 & $17.7\left(27^{c}\right)$ & 24.0 & 33.9 & NA \\
\hline $\begin{array}{l}\text { Resident quality } \\
\text { of life }\end{array}$ & $58.7\left(89^{c}\right)$ & 80.0 & $0.7\left(1^{c}\right)$ & 3.0 & $8.1\left(12^{\mathrm{c}}\right)$ & 17.0 & 32.5 & NA \\
\hline Faculty workload & NA & 0 & NA & 61.6 & NA & 38.4 & NA & NA \\
\hline
\end{tabular}

Abbreviations: $\mathrm{ACGME}=$ Accreditation Council for Graduate Medical Education; NA $=$ not applicable.

a The transitional group of residents were residents who reported they worked as an intern or resident before 2003 implementation of the ACGME duty hour regulation and after the duty hour rules were implemented.

b The uniform group of residents who always worked under the ACGME duty hours responded in one-third of total responses but could not assess before and after these regulations were implemented.

c Percent responses were adjusted mathematically to account for the two-thirds (66\%) of residents who represented the transitional residents (e.g., $41.1 \%$ of residents felt that patient care was improved after the duty hours or $[0.41 / 0.66=61 \%]$ ) to properly represent the rate of responses within this group. 
patient safety errors and the impact of lifestyle on residency and fellowship selection.

\section{ACKNOWLEDGMENT}

The authors thank Cheryl Alementi, Lucy Persaud, Paul Thoresen, the members of the AAN Graduate Education Subcommittee, and the Consortium of Neurology Residents and Fellows for their help and comments as well as the respondents to the survey. Dr. Freeman thanks Kelly Viola, Mayo Academic and Research Support, for assistance.

\section{DISCLOSURE}

Dr. Freeman has served as officer of the American Academy of Neurology, Resident \& Fellow section. Dr. Nolte has served as officer of the American Academy of Neurology, Resident \& Fellow section. Dr. Matthews has served as officer of the American Academy of Neurology, Resident \& Fellow section, and receives research support from the NIH. M. Coleman is an employee of the American Academy of Neurology. Dr. Corboy has served as Chair of the Graduate Education Subcommittee (GES); serves as Editor for Neurology: Clinical Practice and as Section Editor for Neurology Today; serves as a consultant for Bayer Schering Pharma, EMD Serono, Inc., Advanced Studies in Medicine (ASiM), and Novartis; has received research support from Novartis, BioMS Medical, Orasi Medical Inc., the NIH/NINDS, and the National MS Society; and has reviewed files and give expert testimony in medicolegal cases.

\section{REFERENCES}

1. Pedley TA. The changing face of academic neurology. Neurology 1999;53:906-914.

2. Corboy JR, Boudreau E, Morgenlander JC, Rudnicki S, Coyle PK. Neurology residency training at the millennium. Neurology 2002;58:1454-1460.
3. Schuh LA, Adair JC, Drogan O, Kissela BM, Morgenlander JC, Corboy JR. Education research: neurology residency training in the new millennium. Neurology 2009; 72:e15-e20.

4. Bradley WG. Neurology in the next two decades: report of the Workforce Task Force of the American Academy of Neurology. Neurology 2000;54:787-789.

5. Watson JC. Impact of the ACGME work hour requirements: a neurology resident and program director survey. Neurology 2005;64:e11-e15.

6. Adair JC, Rudnicki SA, Boudreau E, Weiner WJ, Coyle PK, Corboy JR. Survey of training programs' means for promoting neurology and attracting trainees. Neurology 2006;67:936-939.

7. Gill DJ, Freeman WD, Thoresen P, Corboy JR. Residency training: the neurology resident case log: a national survey of neurology residents. Neurology 2007;68:e32-e33.

8. Kolasinski SL, Bass AR, Kane-Wanger GF, et al. Subspecialty choice: why did you become a rheumatologist? Arthritis Rheum 2007;57:1546-1551.

9. Landrigan CP, Barger LK, Cade BE, Ayas NT, Czeisler CA. Interns' compliance with accreditation council for graduate medical education work-hour limits. JAMA 2006;296:1063-1070.

10. Institute of Medicine, Board on Health Care Services. Resident duty hours: enhancing sleep, supervision, and safety. Released December 15, 2008. Available at: http:// iom.edu/Reports/2008/Resident-Duty-Hours-EnhancingSleep-Supervision-and-Safety.aspx. 


\section{Neurology}

\section{Results of the American Academy of Neurology Resident Survey \\ W.D. Freeman, C.M. Nolte, B.R. Matthews, et al. \\ Neurology 2011;76; e61-e67 \\ DOI 10.1212/WNL.0b013e318212a871}

\section{This information is current as of March 28, 2011}

\section{Updated Information \& Services}

References

Citations

Subspecialty Collections

Permissions \& Licensing

Reprints including high resolution figures, can be found at: http://n.neurology.org/content/76/13/e61.full

This article cites 9 articles, 5 of which you can access for free at: http://n.neurology.org/content/76/13/e61.full\#ref-list-1

This article has been cited by 8 HighWire-hosted articles: http://n.neurology.org/content/76/13/e61.full\#\#otherarticles

This article, along with others on similar topics, appears in the following collection(s):

Alzheimer's disease

http://n.neurology.org/cgi/collection/alzheimers_disease

Cerebrospinal Fluid

http://n.neurology.org/cgi/collection/cerebrospinal_fluid

MCI (mild cognitive impairment)

http://n.neurology.org/cgi/collection/mci_mild_cognitive_impairment MRI

http://n.neurology.org/cgi/collection/mri

Training-international

http://n.neurology.org/cgi/collection/training_international

Information about reproducing this article in parts (figures,tables) or in its entirety can be found online at:

http://www.neurology.org/about/about_the_journal\#permissions

Information about ordering reprints can be found online:

http://n.neurology.org/subscribers/advertise

Neurology ${ }^{\circledR}$ is the official journal of the American Academy of Neurology. Published continuously since 1951, it is now a weekly with 48 issues per year. Copyright Copyright @ 2011 by AAN Enterprises, Inc.. All rights reserved. Print ISSN: 0028-3878. Online ISSN: 1526-632X.

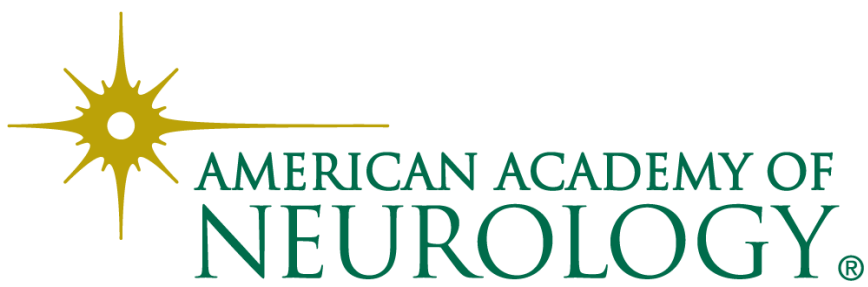

